\title{
Social Capital and Quality of Life in Multi-storey Housing Neighbourhood Community
}

\author{
Hazlina Hamdan, Fatimah Yusof, \\ Marlyana Azziyati Marzukhi, Faizul Abdullah \\ Centre of Studies for Town and Regional Planning, Faculty of Architecture, Planning and Surveying, \\ Universiti Teknologi MARA, 40000 Shah Alam, Selangor, Malaysia \\ hazlina594@salam.uitm.edu.my
}

\begin{abstract}
Social capital is a valuable asset with positive consequences on societal well-being, strengthen neighbourhood and increase the quality of life. The objective of this paper is to analyse a few dimensions of social capital in the multi-storey housing neighbourhoods community with household questionnaires survey of 797 samples. The findings demonstrated the bonding of social capital according to four dimensions. Different neighbourhoods in a different locality with the diversity of its people, and surrounding developments have influenced the pattern of social capital. Social capital in these community creates positive social values that contributes to increasing the quality of life.

Keywords: social capital; quality of life; multi-storey housing; neighbourhoods

eISSN 2398-4279 @ 2018. The Authors. Published for AMER ABRA cE-Bs by e-International Publishing House, Ltd., UK. This is an open-access article under the CC BY-NC-ND license (http://creativecommons.org/licenses/bync-nd/4.0/). Peer-review under responsibility of AMER (Association of Malaysian Environment-Behaviour Researchers), ABRA (Association of Behavioural Researchers on Asians) and CE-Bs (Centre for EnvironmentBehaviour Studies), Faculty of Architecture, Planning \& Surveying, Universiti Teknologi MARA, Malaysia.

DOI: https://doi.org/10.21834/ajqol.v3i9.85
\end{abstract}




\subsection{Introduction}

Social capital is a fourth capital acknowledged following physical, financial, and human capital. It is an asset between people that brought positive consequences for societal wellbeing. The acknowledgement of social capital in the relationships of everyday life is beneficial for society to generate micro-level outcomes such as family well-being, strengthen neighbourhood, and increase the quality of life, in addition to macro level effects such as efficient economies and active society (Stone, W., and Hughes, J. 2002). With an emphasis on empowering communities, social capital is an essential measure to ensure positive relationship among dwellers, build stronger communities, and increase the quality of life. Therefore, the objective of this paper is to assess social capital pattern among households living in multi-storey housing for positive social values towards good living that contribute to the quality of life.

\subsection{Literature Review}

Social capital is the glue that holds the society together (Catts, R and Ozga, J., 2005). It includes the shared values and rules for social conduct expressed in personal relationships, trust, and a common sense of 'civic' responsibility that makes society more than just a collection of individuals (Grootaert, C., 1999). Woolcock and Narayan (2000) outline four common views of social capital: (a) the communitarian, (b) the institutional, (c) the synergy, and (d) the networks. From the four views, the networks are salient in an application of social capital in neighbourhood areas because it emphasizes intra and extra community relationships (Bowen et al., 2000). Intracommunity ties are bonding social capital (social capital that exists within a neighbourhood) and extra community ties are bridging social capital (social capital that exists between a neighbourhood and other neighbourhoods or organizations) (Bowen et al., 2000). Bonding social capital is the network of trusting relationships, or social cohesion and trust, among members of a neighbourhood; bridging social capital is the trusting network of relationships between members of a neighbourhood and outside organizations and institutions. (Brisson and Usher, 2005). Bonding and bridging social capital leads to happier, and healthier lives, feel safer and greater belonging, effective governance and even enhanced economic achievement (Pitchford, 2008; Fukuyama, 1995; National Statistics, 2001) So, social capital is a network, interaction, and connection of people within a community. It has also consisted the norms, relationships, values and informal sanctions that shape the quantity and cooperative quality of society's social interactions (Aldridge, S. et al., 2002). Neighbourhoods in housing area including multi-storey housing can create and use network, interaction and connection to improve the quality of life as well as help get information, ideas, influences, and resources.

Overall well-being and quality of life are linkages of people to get acquainted with their surroundings, participate in community and daily activities, feel connected, and have a strong sense of place. According to Burchell, R., et.al. (1998), low-density development weakens households' connections to both immediate neighbours and also with the community that leads to encourages unsociable values. Meanwhile, low-income groups usually reside in high-density housing supposed to have close contact with immediate neighbours. However, 
according to a study, high density, "along with diversity and the anonymity afforded by urban life, increased stress, severed traditional bonds and led to a decline in the community or social ties" (Freeman, L., 2001). "By bringing too many individuals in close contact with one another, high densities served to increase loneliness as individuals became reserved toward one another as means of dealing with the resultant sensory overload" (Freeman, L., 2001).

Also, a study on social capital in Britain suggests that there is a class factor, with middleclass people being more likely to be members of voluntarily or civic associations while working class households enjoy higher levels of informal sociability (Christ, 2009). The geographical setting either landed or multi-storey housing areas as well as a community with socioeconomic diversity can influence the degree of social capital. Studies have also shown the impacts of social capital on some measures of socioeconomic characteristics such as income and education. Narayan and Pritchett (1999) in a study in Tanzania found that social capital is an important determinant of household income. According to a study in Nigeria by Yusuf (2008), also found that social capital affects household welfare. The multifaceted phenomenon of social capital linked to numerous social outcomes. The outcomes brought by different degree of social capital in various types of housing area enable the bonding, bridging and linking of the community towards the better quality of life. This paper examines how a few dimensions of social capital variables explain the bonding of social capital in a multi-storey housing community.

\subsection{Methodology}

The study area consists of three neighbourhoods within three local authority areas in Klang Valley, Malaysia. The neighbourhoods are Kota Damansara in Petaling Jaya Municipality area, Puchong in Subang Jaya Municipality area, and the third area, Kajang in Kajang Municipality (Figure 1). The neighbourhoods chosen are those of multi-storey housing comprises of low cost, medium, and high-medium cost houses. These neighbourhoods are the suburban area within Klang Valley and have become a fast growing neighbourhood in the last 15 to 20 years. Neighbourhoods in Kajang are the earliest and older housing area Meanwhile; Kota Damansara is the newest suburban housing development among the three neighbourhoods.

The research undertakes household questionnaire surveys with 797 samples based on systematic random sampling method. This method of sampling selects units at a fixed interval throughout the sampling frame. The first unit of housing block of the study area is randomly selected, and then the questionnaire is distributed to every three houses. If there is a vacant and unwilling household to participate, the three intervals are still used for the next subsequent home.

Measurements on social capital take many approaches. There are three types of social capital - bonding, bridging and linking to determine the level of social capital from micro to macro level. Social capital can be viewed to constitute six dimensions. The dimensions are groups and networks; trust; collective action and cooperation; social cohesion and inclusion; information and communication; and empowerment and political action. Social capital inherently is good and having social interaction and knowing many friends could lead to the 
feeling of good and may raise individual or societal level of life satisfaction (Roslan Abdul Hakim, et al., 2010). This paper focuses on four dimensions of bonding social capital that link to quality of life. The four dimensions are groups and networks; trust; collective action and cooperation; social cohesion and inclusion, with selected variables as indicated in Table 1.

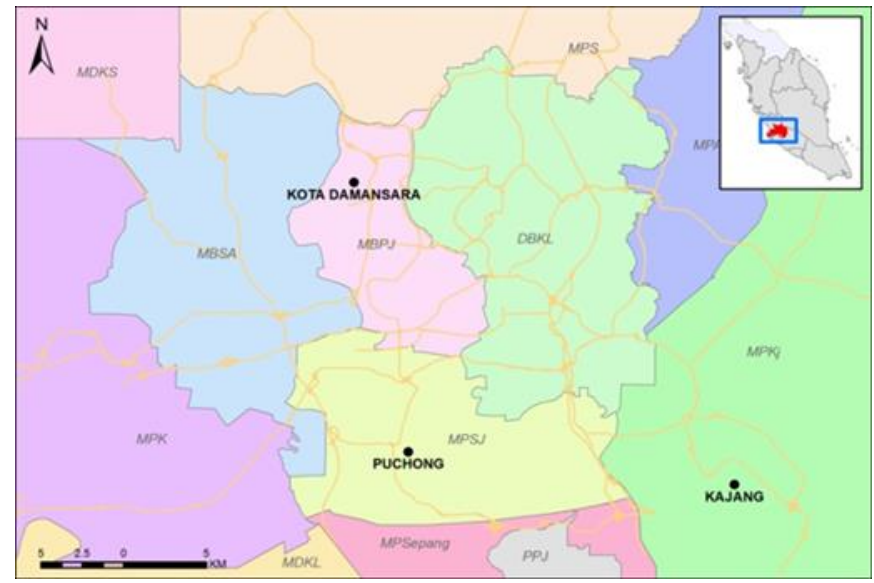

Figure 1: Location of Study Area in Klang Valley, Malaysia

Table 1: Social Capital Dimensions and Related Variables

\begin{tabular}{|l|l|}
\hline Social Capital Dimension & Variables \\
\hline Groups and networks & Relationship and Networking \\
\hline Trust & Level of trust in the community \\
\hline Collective action and Cooperation & $\begin{array}{l}\text { i)Helping each other in neighborhood } \\
\text { ii)Cooperation in neighborhood activities }\end{array}$ \\
\hline Social cohesion and inclusion & $\begin{array}{l}\text { i) Strong feelings of togetherness } \\
\text { ii)Sense of belonging }\end{array}$ \\
\hline
\end{tabular}

The reliability test was conducted for variables for group and networks and trust, to determine whether these variables are consistent, hence its reliability as the measurement. The results for the variables tested for relationship and networking have a Cronbach's alpha value of 0.594 . The Cronbach's alpha value for the level of trust is 0.822 . The sizes of the alpha values in social science studies imply that the variables used are reliable measurements of the perceptions of respondents. Table 2 presents the summary statistics of the One-sample Kolmogorov-Smirnov (K-S) Test of Normality. The K-S's Z values are significant $(p<0.01)$. Thus, concluded that the individual observation values of the variables not normally distributed. Thus, in the further analysis involving elements which score not normally distributed, the nonparametric statistical tool is used for the two variables. For other remaining four variables, the analysis was done descriptively. 
Table 2: Summary Statistics of Normality Test

\begin{tabular}{|ll|l|l|}
\hline \multicolumn{2}{|l|}{ Variable } & Kolmogorov-Smirnov Z statistics & $p$-value \\
\hline 1. & $\begin{array}{l}\text { Relationship and } \\
\text { Networking }\end{array}$ & 2.698 & $0.000^{* *}$ \\
\hline $2 . \quad$ Level of trust & 2.034 & $0.001^{* *}$ \\
\hline
\end{tabular}

${ }^{* *}$ Significant at 0.01

\subsection{Findings and Discussions}

\subsection{Groups and Networking}

For groups and networking, the variables tested are the household relationship with their networking that constitutes four categories- friends, neighbours, family, and colleagues. The variable assesses to what extent the respondent had the networks with the identified groups mentioned according to the three neighbourhoods.

Table 3: Groups and Networking in Neighbourhoods

\begin{tabular}{|c|c|c|c|c|c|c|c|c|c|}
\hline Variable & Neighbourhood & $\begin{array}{l}\text { Mean } \\
\text { Rank }\end{array}$ & $\begin{array}{l}x^{2} \\
\text { value }\end{array}$ & $p$-value & Statistics & Neighbours & Colleague & Family & Friend \\
\hline \multirow{6}{*}{$\begin{array}{l}\text { a)Relationship } \\
\text { and } \\
\text { Networking }\end{array}$} & \multirow{2}{*}{ Puchong } & \multirow[b]{2}{*}{310.13} & \multirow{6}{*}{60.629} & \multirow{6}{*}{$0.000^{\text {** }}$} & Mean & 3.09 & 4.78 & 5.81 & 4.15 \\
\hline & & & & & Std. dev & 1.350 & 1.459 & 1.489 & 1.519 \\
\hline & \multirow{2}{*}{$\begin{array}{l}\text { Kota } \\
\text { Damansara }\end{array}$} & \multirow[b]{2}{*}{438.25} & & & Mean & 4.13 & 4.38 & 6.39 & 4.82 \\
\hline & & & & & Std. dev & 1.360 & 1.019 & 0.928 & 1.280 \\
\hline & \multirow{2}{*}{ Kajang } & & & & Mean & 4.27 & 4.67 & 6.59 & 4.62 \\
\hline & & 449.12 & & & Std. dev & 0.928 & 0.906 & 0.844 & 1.429 \\
\hline
\end{tabular}

${ }^{* *}$ Significant at 0.01

Note: Scale variable a) 1.00 to 2.99- Not close; scale 3.00 to 4.99- somewhat close; scale 5.00 to 6.99 - close

Based on Table 3, the results show that the relationship of the respondents with their networks differ between the three neighbourhoods $(p<0.01)$. Specifically, those staying at Kajang (mean rank 449.12) are closer with all four categories, followed by those staying at Kota Damansara (mean rank 438.25) and Puchong (mean rank 310.13).

According to the mean score, respondents perceived to have a close relationship to family members in all three neighbourhoods. The mean also indicated that relationship and networking are in the scale of somewhat close to the colleague, friends, and neighbours for all three areas. However, the mean of relationship with neighbours is rather weak compared to the other three categories. Nevertheless, those who live in Kajang have better social networks compared to the other two areas. Kajang is the earliest to develop and older neighbourhood thus the community in Kajang has well established to have a better relationship and social networks. The patterns and intensity of networks are close first with family, friends, colleagues and neighbours. The bonding of social networks indicates the social capital has very much existed in dense or closed networks and helps people "get by" in life on a daily basis (Stone, W. et.al., 2003). For groups and networking, the social capital concern here is the bonding that existed between individuals and their surroundings. What the pattern of bonding existed is the same but with different significance between the three neighbourhoods. With this kind of bonding, it helps people to get support from the familiar 
groups in their life. This way it can lead to the feeling of good about oneself and raise the level of satisfaction towards a better quality of life.

\subsection{Trust}

The next variable is trust in the neighbourhood (Figure 2). Most of the respondents in Kajang and Kota Damansara have medium trust towards the neighbourhood. Only Puchong area shows little trust $(52.1 \%)$. The results show (Table 4 ) that trustworthily differs between the three areas $(p<0.01)$. Respondents were staying at Kajang area (mean rank 499.63), the level of trust towards the community surrounding them ranks first, followed by those staying at Kota Damansara (mean rank 348.98) second and third those staying at Puchong (mean rank 346.51). People in urban areas are very cautious regarding trusting other people especially living in the multi-storey housing with diverse socioeconomic backgrounds and challenging community behaviour.

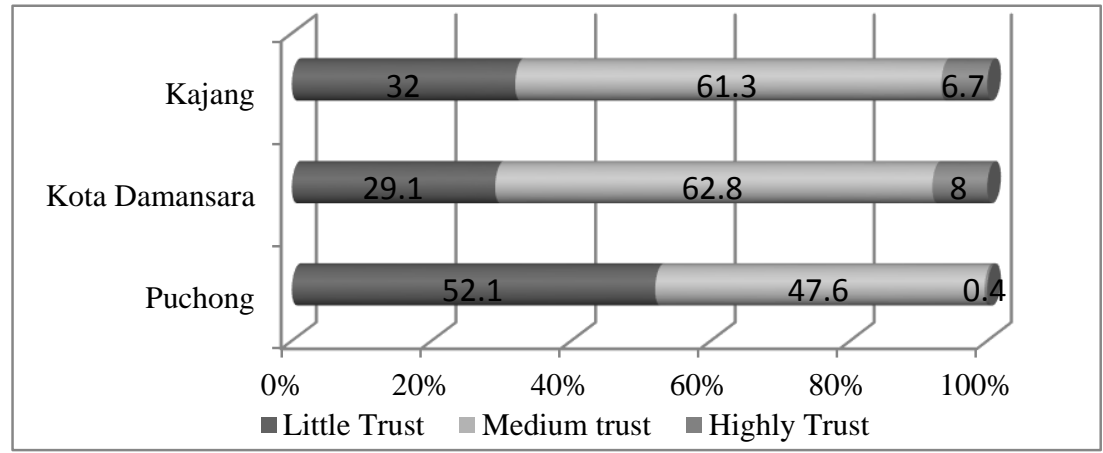

Figure 2: Level of Trust toward Neighbourhood

The multi-storey (high density) housing sometimes is portrayed by having a low standard of living due to social problems, unsafe, and undesirable surroundings (Hazlina, etc., 2014). Trust is a bridge, links individuals together in society. The level of trust in the study area is somehow on the scale of low to medium level. The intensity of developments surrounding the neighbourhoods that have affected the everyday life of people leading to the feelings of insecure. The level of trust indicates that living in multi-storey housing, knowing more people around, and with diversity and anonymity afforded by urban life (Freeman, L., 2001) can influence the level of trust within a community.

Table 4: Summary Statistics of Kruskal-Wallis Test: Difference in Level of Trust

\begin{tabular}{|l|l|l|l|}
\hline Neighborhood & Mean rank & \multirow{2}{*|}{$\chi^{2}$ value } & $p$-value \\
\hline Puchong & 346.51 & \multirow{2}{*}{$0.000^{* *}$} \\
\cline { 1 - 2 } Kota Damansara & 348.98 & \\
\hline Kajang & $499.63 \quad{ }^{* *}$ Significant at 0.01 & \\
\hline
\end{tabular}




\subsection{Collective Action and Cooperation}

In a neighbourhood, collective actions among community members are important for the community to be vibrant. Collective action and cooperation are referred to how well the community helps each other and what are the activities that hold the community together. Figure 3 shows respondents in all three areas have a good spirit in helping each other. The percentage in the category of always helping is highest $(24.5 \%)$ in Kajang compared to the other two areas. For the category of sometimes helping each other, the percentage is high in Kota Damansara(72.8\%) and Puchong (71.5\%).

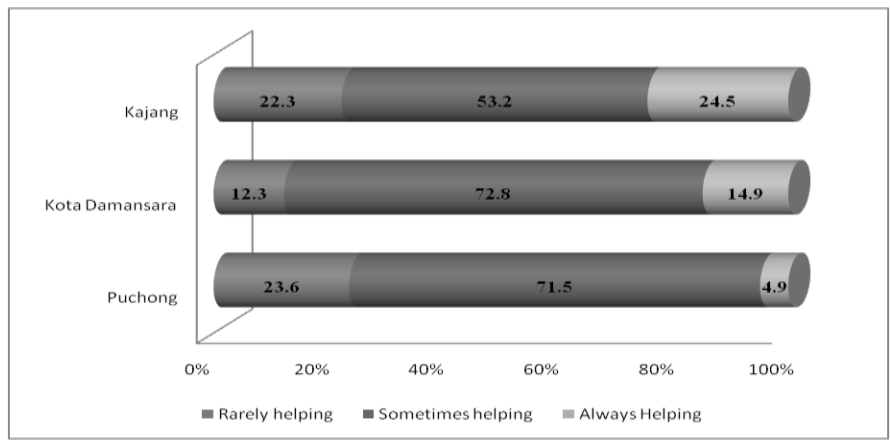

Figure 3: Percentage of Helping Each Other in Neighborhood

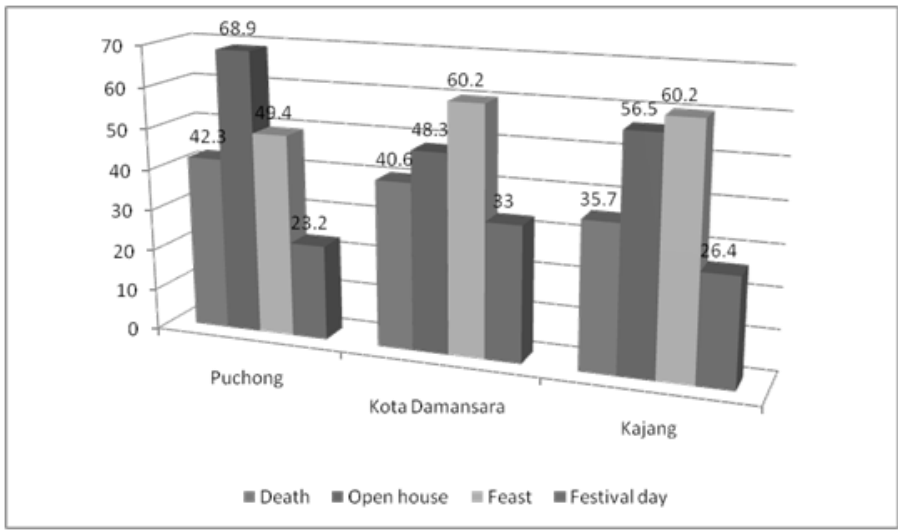

Figure 4: Cooperation in Neighbourhoods

Further, look at cooperation in neighbourhoods (Figure 4), it shows that all three areas have a good relation in activities involving participation in a community. The most involvement is attending an open house and feast. Visiting due to death of neighbours also very significant, which shows the people have collective action and cooperation regardless of sad and good times. Collective actions and cooperation create mutual benefits in society. Communal living enhanced neighbourhood relations. When people in a neighbourhood were 
helping each other, they will become acquainted and form a habit of coming together in neighbourhood activities. For all three areas investigated, the findings indicate collective actions and cooperation at a satisfactory level and the community show good spirits when it comes to communal activities that able to improve community well-being.

\subsection{Social Cohesion and Inclusion}

According to Cloete, P., and Kotze, F. (2009) the term social cohesion signifies the bonding between people and groups or "glue" that binds people in positive relationships. It is a desirable quality in social relations where individuals, groups or larger aggregates share a living space and interact (Cloete, P., and Kotze, F., 2009). The social cohesion and inclusion analysed are strong feelings of togetherness and sense of belonging in the neighbourhood. As shown in Table 5, respondent's perceptions regarding feelings of togetherness vary between neighbourhoods.

Table 5: Perceptions on Social Cohesion and Inclusion Neighborhoods

\begin{tabular}{|l|l|l|l|l|l|}
\hline Neighborhood & \multicolumn{3}{|c|}{$\begin{array}{l}\text { Feelings of } \\
\text { Togethernss } \\
(\%)\end{array}$} & $\begin{array}{l}\text { Sense } \\
\text { of }\end{array}$ & $\begin{array}{l}\text { Belonging } \\
(\%)\end{array}$ \\
\hline & $\begin{array}{l}\text { Not } \\
\text { Strong }\end{array}$ & $\begin{array}{l}\text { Medium- } \\
\text { Strong }\end{array}$ & $\begin{array}{l}\text { Very } \\
\text { Strong }\end{array}$ & $\begin{array}{l}\text { Low } \\
\text { Level }\end{array}$ & $\begin{array}{l}\text { High } \\
\text { Level }\end{array}$ \\
\hline Puchong & 58.1 & 37.1 & 4.9 & 60.7 & 39.3 \\
\hline $\begin{array}{l}\text { Kota } \\
\text { Damansara }\end{array}$ & 53.6 & 19.5 & 26.8 & 43.3 & 56.7 \\
\hline Kajang & 21.9 & 51.7 & 26.4 & 43.1 & 56.9 \\
\hline
\end{tabular}

For Puchong and Kota Damansara, more than half of respondents feel that they do not have strong feelings of togetherness in their neighbourhoods. However, for Kajang residences, the feelings are different with more than three quarters have medium to very strong feelings of togetherness in the neighbourhood. This variation perhaps due to the socioeconomic composition and location of the neighbourhoods. The community is close to each other in Kajang because it is an established neighbourhood where people were living in this area for a longer duration and had good interaction with a high level of sense of belonging (56.9\%). Meanwhile, the feelings of togetherness in Puchong are not strong due to the people in this neighbourhood feels they are less close with the neighbours, have a low level of trust, thus influence the degree towards a low-level sense of belonging $(60.7 \%)$. Kota Damansara is the latest suburban area amongst the three neighbourhoods. Though, the residences in this area may not know each other very well, but they value their community with a high-level sense of belonging (56.7\%).

With regards to social cohesion and inclusion, the findings from the analysis above showed some conflicting views. Although the level of collective actions and cooperation is good, the social cohesion and inclusion are otherwise. When it comes to feelings of togetherness, variations exist among the three areas. The feelings of togetherness may diminish, but the residences still can participate in communal activities. For the area with little trust towards the neighbourhood, the level of sense of belonging is lower compared to the 
area with more trust and a higher level of sense of belonging.

\subsection{Conclusion}

Overall, the assessment has demonstrated variations pattern in four selected social capital dimensions. In this study, social capital is essential in explaining the quality of life, but it varies according to characteristics of society living in one area. Close ties to social groups and networking, involvement in collective actions, tolerance in the level of trust and sense of neighbourhood contribute to the satisfaction in life. According to Marans, R. W. (2011), satisfaction with living might include satisfaction with housing, neighbourhood and community and these satisfactions might influence the overall satisfaction with life. People do value their neighbourhood differently to have satisfaction in life. As long as people are happy in daily life circumstances, this could contribute to increasing quality of life.

This paper has shown how bonding social capital selected dimensions operated in urban neighbourhoods of multi-storey housing at a micro level. The findings of this study depicted different neighbourhoods in a different locality with the diversity of its people, and surrounding developments have influenced the level of social capital dimensions. However, how neighbourhood perceived their level of social capital, it would suggest that social capital is essential for community development via social network and trustworthy of the people within the community, collective action and cooperation that bring people together and social cohesion and inclusion that increase the neighbourhood values. All these generate positive social capital outcomes and play a role in improving the quality of life for people living in multistorey urban housing.

\section{Acknowledgement}

This study acknowledges the funds given by the Ministry of Higher Education, Malaysia through Universiti Teknologi MARA under Fundamental Research Grant Scheme (FRGS): 600-RMI/SSP/FRGS 5/3/Fspu (1/2011.)

\section{References}

Aldridge, S. etc, (2002) Social Capital: A Discussion Paper. Performance and Innovation Unit of Cabinet Office, UK,

Bowen, G. L., Martin, J. A., Mancini, J. A., \& Nelson, J. P. (2000). Community capacity: Antecedents and consequences. Journal of Community Practice, 8(2), 1-21.

Brisson, D.S. and Usher, C.L., (2005) Bonding Social Capital in Low Income Neighbourhoods. Family Relations 54, pp 644-653.

Bullen, Paul and Onyx, Jenny. (1998) Measuring Social Capital in Five Communities in NSW. Centre for Australian Community Organizations and Management (CACOM). Working paper series, No 41

Burchell, R. et al. (1998). The Costs of Sprawl-Revisited. (Transit Cooperatives Research Program 34) Washington 
D.C., National Academy Press.

Catts, R. and Ozga, J. (2005) What is Social Capital and how might it be used in Scotland's Schools? No. 36, December2005. http://www.ces.ed.ac.uk/PDF\%20Files/Brief036.pdf. Date Retrieved September 26, 2013

Christ, A. (2009). The Well Connected Community: A Networking Approach to Community Development. Bristol, University of Bristol Policy Press.

Cloete, P. and Kotze, F. (2009) Concept Paper on Social Cohesion/Inclusion in Local Integrated Development Plans. Commissioned by Department of Social Development, Republic of South Africa.

http://www.presidentsaward.co.za/wp-content/uploads/2013/04/Social-Cohesion-Final-Draftcorrect-IDP DSD.pdf. Date Retrieved October 8, 2013.

Debertin, D.L. (n.d) A comparison of social capital in rural and urban settings.<http://www.uky.edu/ deberti /socaea.htm. Date Retrieved July 20,2013

Freeman, L. (2001) "The Effects of Sprawl on Neighborhood Social Ties: An Explanatory Analysis". Journal of American Planning Association, 67, 1:69-77.

Fukuyama, Francis. (1995) Trust: The Social Virtues and the Creation of Prosperity. London, Penguin.

Grootaert, C. (1999). Local Institutions and Service Delivery in Indonesia. Local Level Institutions Working PaperNo.5http://www.worldbank.org/socialdevelopment.Date Retrieved October 10, 2013.

Hazlina Hamdan, Fatimah Yusof and Marlyana Azziyati Marzukhi (2014). Social Capital and Quality of Life in Urban Neighborhood High Density Housing. Procedia - Social and Behavioral Sciences 153, pp. 169 - 179.

Marans, R. W. (2011) Quality of Life Studies: An Overview and Implications for Environment- Behaviour Research. Paper Presented at Asia Pacific Conference on Environment Behavior Studies, Famagusta, North Cyprus, 7-9 December.

Narayan, Deepa \& Pritchett, Lant, (1999). Cents and Sociability: Household Income and Social Capital in Rural Tanzania. Economic Development and Cultural Change, vol. 47(4), pages 871-97.

National Statistics (2001). Social Capital: A review of the literature, London: Office for National Statistics. http://www.statistics.gov.uk/socialcapital/downloads/soccaplitreview.pdf. Date Retrieved September 16, 2013.

Pitchford, Michael.(2008). Making Spaces for Community Development. Bristol: Policy Press.

Roslan Abdul Hakim, etc (2010) The Relationship Between Social Capital and Quality of Life Among Rural Households in Terengganu Malaysia. International Journal of Sustainable Development Vol. 1:05, pp. 99-106.

Stone, W. and Hughes, J. (2002). Social Capital: Empirical Meaning and Measurement Validity. Australian Institute of Family Studies, Research paper No.27. http://www.aifs.org.au/institute/pubs/rp27/Date Retrieved October 18, 2013.

Stone, W., Gray, M. and Hughes, J (2003) Social Capital at Work. Australian Institute of Family Studies. Research paperNo.31. http://www.aifs.gov.au/institute/pubs/respaper/RP31.pdf Date Retrieved 20/3/2013.

Woolcock, M., \& Narayan, D. (2000). Social capital: Implications for development theory, research, and policy. The World Bank Research Observer, 15, 225-249.

Yusuf, S.A. (2008) Social Capital and Household Welfare in Kwara State, Nigeria. Journal of Human Ecology., 23(3): 219-22. 